\title{
Determination of microphytobenthos PSII quantum efficiency and photosynthetic activity by means of variable chlorophyll fluorescence
}

\author{
Jacco Kromkamp*, Christiane Barranguet**, Jan Peene
}

Netherlands Institute for Ecology, Centre for Estuarine and Coastal Ecology, PO Box 140, 4400 AC Yerseke, The Netherlands

\begin{abstract}
A pulse amplitude modulated fluorometer (PAM) was used to investigate photosynthetic activity of microphytobenthos on an intertidal mudflat. Spectral irradiance measurements indicate that $75 \%$ of the signal detectable by the PAM originates in the upper $150 \mu \mathrm{m}$ of the sediment. From the photosynthetic electron transport rate $(E T R)$ measurements, it was concluded that the PAM could be used to observe changes in photosynthetic parameters during the day or the season. Photoacclimation to lower irradiance was indicated by changes in the maximum ETR and the saturating photon irradiance parameter $I_{\mathrm{k}}$. When cores were exposed to a high photon irradiance for several hours, vertical migration could be followed using reflectance spectra. The data also showed that the benthic algae did not seem to experience photoinhibition or $\mathrm{CO}_{2}$ limitation. To explain this, it is hypothesised that there is a continuous vertical migration in the top layer of the sediment, where algae can avoid photoinhibition due to prolonged periods of high irradiance and lack of $\mathrm{CO}_{2}$ by migrating downwards while others migrate upwards.
\end{abstract}

KEY WORDS: Microphytobenthos - Chlorophyll fluorescence P Photosynthesis - Vertical migration C-limitation

\section{INTRODUCTION}

Intertidal areas are a common feature of estuaries. The microphytobenthos colonising the intertidal flats form an important component of the estuarine ecosystem. Benthic algae are an important food-source for surface dwellers and deposit feeders (Sullivan \& Moncreiff 1990, Heip et al. 1995) and are responsible for sediment stabilisation by excretion of carbohydrates (Holland et al. 1974, Paterson 1989, Yallop et al. 1994).

Microphytobenthos can reach high densities on intertidal flats and, consequently, microphytobenthos primary production can be an important fraction of total primary production in the system. Colijn (1983) estimated that microphytobenthos contributed $20 \%$ to total primary production in the Ems-Dollard estuary (The Netherlands). Sullivan \& Moncreiff (1988) estimated

\footnotetext{
-E-mail: kromkamp@cemo.nioo.knaw.nl

- Present address: University of Amsterdam, Department of Aquatic Ecotoxicology, Kruislaan 320, 1098 SM Amsterdam, The Netherlands
}

benthic microalgal production to be one third of total primary production in a Mississippi (USA) salt marsh.

Measuring microphytobenthos primary productivity is not easy because the activity seems highly variable, both on the hourly and monthly time scales. Microphytobenthos production seems to be positively correlated to elevation of the tidal flat, which is probably due to the influence of the length of the photoperiod, and to the clay content, which is related to hydrodynamic activity (de Jong \& de Jonge 1995). Variation in photosynthetic parameters during low tide has also been observed (Blanchard \& Cariou-LeGall 1994, Kromkamp et al. 1995a, MacIntyre \& Cullen 1995) and has been attributed to vertical migration of benthic diatoms, which might be influenced by tidal stage and sun angle (Pinckney \& Zingmark 1991), and $\mathrm{CO}_{2}$-limitation caused by high pH-values (Rasmussen et al. 1983, de Jong et al. 1988)

Methods to estimate primary production by microphytobenthos use chambers (see Heip et al. 1995 and references therein), the ${ }^{14} \mathrm{C}$-technique, or oxygen micro-electrodes (e.g. Revsbech \& Jørgensen 1983). 
All of these methods have their own advantages and disadvantages, which will be briefly discussed later We chose to investigate whether it was possible to measure photosynthetic activity of microphytobenthos on intertidal flats using a pulse amplitude modulated fluorometer (PAM). This technique allows us in principle not only to measure photosynthetic activity rapidly in a non intrusive way, but also to look at processes like quantum efficiency, photoprotection and photoinhibition, which will give extra information on the physiological state of the benthic microalgae.

Variable chlorophyll (chl) fluorescence originates mainly from light emission in chl a-containing photosystem II complexes (PSII). Excitation energy obtained by absorption of the light harvesting pigment protein complexes of PSII can not only be used for photochemistry, but can also be lost by thermal dissipation (heat) or fluorescence. These processes compete and influence the energy conversion efficiency or quantum yield (see Krause \& Weis 1991, Kolber \& Falkowski 1993, Dau 1994 and Horton \& Ruban 1994 for reviews). Linear electron transport will only commence following charge separation. When the cells are fully dark adapted, and not photoinhibited, the primary electron

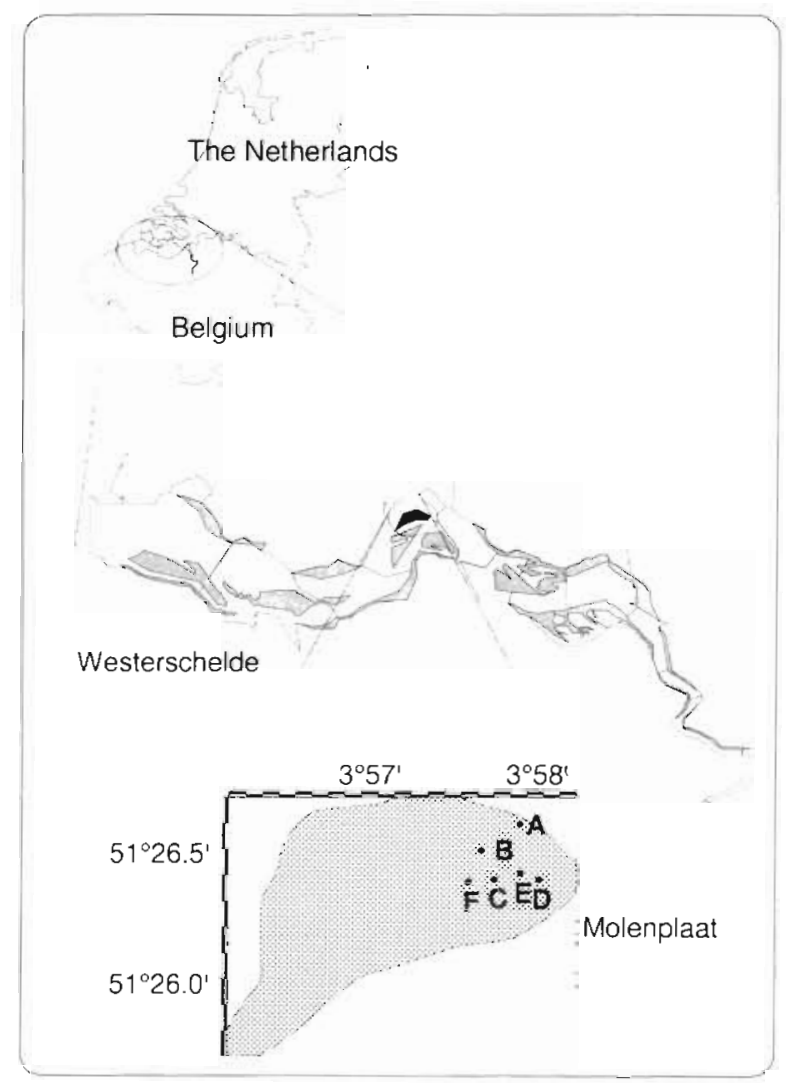

Fig. 1 Location of the Molenplaat in the Westerschelde estuary (The Netherlands) and the sampling stations on the intertidal flat acceptor of PSII, $Q_{A}$, is in the oxidized state (all reaction centres are 'open'), non-photosynthetic energy dissipating mechanisms will be minimal, and the quantum yield will be maximal. Closure of PSIl reaction centres by capture of irradiance will increase the fluorescence yield and induce energy-dissipating processes [non-photochemical ( $\mathrm{qN}$ ) quenching]. This will decrease the quantum efficiency. When all energydissipating mechanisms are saturated, photoinhibition will occur, leading to net degradation of the $D_{1}$ reaction centre II protein (Ohad et al. 1994). In this case, qN quenching will slowly relax when the cells are transferred to the dark. However, (normally short lived) qN quenching can also be induced at non-saturating irradiances. Hence the relaxation of qN quenching in darkness or dim irradiance conditions can be used to determine whether photosynthesis is down regulated ('dynamic inhibition') or whether chronic photoinbibition occurred (Osmond 1994).

In this paper we investigated whether the PAM technique could be used to follow changes in photosynthetic activity of microphytobenthos. Our results show that this is indeed possible.

\section{METHODS}

Sampling sites. Microphytobenthos cores were taken at several stations on an intertidal flat (Molenplaat) in the central part of the Westerschelde estuary (SW Netherlands, Fig. 1). Most of the cores $6 \mathrm{~cm}$ diameter) were taken at $\mathrm{Stn} B$, which was visited at least monthly. The cores, each in a tube sealed with a rubber stopper at the bottom, were taken to the ship (RV 'Luctor') in a coolbox, where the PAM measurements were carried out. The first measurements were taken within half an hour after sampling. In order to allow repetition of the measurements during the day, the cores were exposed to the daily surface irradiance by placing them on the deck of the ship; the temperature was kept approximately constant by placing the tubes containing the cores in water, but leaving the surfaces of the cores dry. Nevertheless, the core temperature in summer could be raised by $2^{\circ} \mathrm{C}$, which, however, also happened in the field. The cores did not dry out during the treatments, as a little water was always visible on the surface. Hence, the cores experienced conditions similar to those in the field. Four additional cores (2.5 cm diameter) were taken for pigment analyses. They were sliced immediately after being brought on board. The first $1 \mathrm{~mm}$ of the sediment was extruded using a piston manipulated with a screw, one whole turn equivalent to $1 \mathrm{~mm}$. The four $1 \mathrm{~mm}$ slices were pooled and frozen at $-80^{\circ} \mathrm{C}$ and lyophilized as soon as possible. They were stored in the dark at $-80^{\circ} \mathrm{C}$ until 
Table 1 . Sediment characteristics of the sampling stations at the Molenplaat (Westerschelde estuary, The Netherlands) in March 1995. Grain sizes are given in parentheses

\begin{tabular}{|lccc|}
\hline Stn & $\begin{array}{c}\% \text { silt } \\
(<50 \mu \mathrm{m})\end{array}$ & $\begin{array}{c}\% \text { fine sand } \\
(50 \text { to } 113 \mu \mathrm{m})\end{array}$ & $\begin{array}{c}\% \text { medium sand } \\
(262 \text { to } 564 \mu \mathrm{m})\end{array}$ \\
\hline A & 10.32 & 35.58 & 44.21 \\
B & 16.24 & 34.05 & 39.89 \\
C & 16.24 & 37.53 & 35.17 \\
D & 3.93 & 40.62 & 51.10 \\
E & 4.53 & 48.18 & 43.03 \\
F & 16.65 & 39.52 & 32.66 \\
\hline
\end{tabular}

analyses. Water samples were taken near the intertidal flat. The average salinity of the water was approximately $20 \mathrm{psu}$. Some sediment characteristics of the Molenplaat are given in Table 1.

Fluorescence measurements. Variable fluorescence was measured with a PAM 101-103 fluorometer (Walz, Effeltrich, Germany), which controlled the Schott KL1500/E light source used for administering the saturating irradiance pulses. The photon flux densitiy (PFD) of the irradiance pulse was more than $10000 \mu \mathrm{mol} \mathrm{m} \mathrm{m}^{-2} \mathrm{~s}^{-1}$, i.e. high enough to close all reaction centers. The pulses were administered at $20 \mathrm{~s}$ intervals. We made the pulse length, which varied between 500 and $700 \mathrm{~ms}$, as short as possible in order to avoid an intrusive effect of the pulses. However, we carefully checked before each measurement whether maximum fluorescence $\left(F_{\mathrm{m}}\right)$ was correctly measured by changing the pulse length period and intensity. For actinic irradiance, a Schott KL1500 light source was used in combination with the PAM fiberoptics. Ten exposures ( 2 min each) were made with PFDs ranging from 0 to $1500 \mu \mathrm{mol} \mathrm{m}^{-2} \mathrm{~s}^{-1}$ in order to construct photosynthesis (i.e. electron transport rate or ETR) irradiance curves. The resulting 6 datapoints per PFD were averaged, and these were fitted as a function of PFD according to Platt \& Jassby (1976) using a least-squares method. The $95 \%$ confidence interval was generally less than $4 \%$ of the mean. The photon irradiance was adjusted by changing the voltage of the Schott KL1500 lamp. The tip of the fiberoptic was mechanically positioned perpendicular to the core surface, and the distance to the core surface was approximately $2 \mathrm{~mm}$.

Quenching coefficients were calculated after van Kooten \& Snel (1990).

The maximum energy conversion efficiency or quantum efficiency of PSII charge separation $\left(\phi_{\mathrm{P}}{ }^{\circ}\right)$ is calculated as:

$$
\phi_{\mathrm{P}}^{0}=\left(F_{\mathrm{m}}-F_{\mathrm{o}}\right) / F_{\mathrm{m}}=F_{\mathrm{v}} / F_{\mathrm{m}}
$$

where $F_{0}$ is the minimum fluorescence, $F_{\mathrm{m}}$ is the maximum fluorescence and $F_{\mathrm{v}}$ is the maximum variable fluorescence yield of a minimally 15 min dark-adapted sample.

According to Genty et al. (1989), the effective quantum efficiency of charge separation in actinic irradiance is

$$
\phi_{\mathrm{p}}=\left(F_{\mathrm{m}}{ }^{\prime}-F_{\mathrm{s}}\right) / F_{\mathrm{m}}{ }^{\prime}=\Delta F / F_{\mathrm{m}}{ }^{\prime}
$$

where $F_{\mathrm{rn}}{ }^{\prime}$ is the maximum fluorescence in actinic light, $F_{\mathrm{s}}$ is steady-state fluorescence in actinic light, and $\Delta F$ is variable fluorescence in actinic light. $\phi_{\mathrm{p}}$ can be used to calculate the linear rate of photosynthetic electron transport (ETR) as (Genty 1989, Kolber \& Falkowski 1993, Hofstraat et al. 1994):

$$
E T R=\phi_{\mathrm{P}} \times \mathrm{PFD} \times \sigma_{\mathrm{PSI}}
$$

where $\sigma_{\text {PSII }}$ is the functional cross section of PSII. The product of PFD and $\sigma_{P S I}$ equals the amount of irradiance absorbed by a PSII unit. ETR is called $\mathrm{J}_{\mathrm{e}}$ by Hofstraat et al. (1994). As we could not measure $\sigma_{\mathrm{psI}}$, relative ETR was calculated as $\phi_{\mathrm{P}} \times \mathrm{PFD}$.

Irradiance measurements. During the PAM measurements the photon irradiance at the surface of the sediment was measured as the voltage applied to the lamp of the Schott KL1500 light source. This voltage was calibrated against a MACAM SD101 cosine corrected PAR sensor. Because we changed the irradiance by changing the voltage of the lamp, the spectral characteristics of the irradiance changed. However, from spectroradiometric measurements, carried out using a MACAM SR9910 PC spectroradiometer fitted with a cosine sensor, we concluded that this spectral change was not very important, as the amount of light energy between 400 and $550 \mathrm{~nm}$ relative to total PAR increased from 17 to $26 \%$ when going from low to saturating irradiances.

Spectral reflectance of the sediment was measured by feeding the reflected light collected by the fiberoptics of the PAM into a MACAM SR9910 PC spectroradiometer

Attenuation coefficients of the sediment were determined by measuring the light penetration through a moisturised $1 \mathrm{~mm}$ thick layer of sediment. A $1 \mathrm{~mm} \mathrm{sec-}$ tion of the core was sliced using the piston as described above. This was resuspended and left to settle in a bottle with a diameter identical to that of the core. As a reference measurement the bottle was filled with an identical volume of water. The Schott KL1500 halogen lamp was used as light source, and the photon irradiance was measured at $1 \mathrm{~nm}$ intervals using the MACAM spectroradiometer fitted with a quartz fiber and cosine sensor. The irradiance attenuation coefficient $K_{\mathrm{d}, \lambda}\left(\mathrm{mm}^{-1}\right)$ was calculated as:

$$
\mathrm{PFD}_{z, \lambda}=\mathrm{PFD}_{0, \lambda} \times \mathrm{e}^{-K_{\mathrm{d}, z \lambda \lambda}}
$$

where $z$ is the thickness of the sediment slice $(1 \mathrm{~mm})$. 
Pigment analyses. From the 0 to $1 \mathrm{~mm}$ layer, 4 replicates per station were extracted in $95 \%$ methanol and buffered with ammonium acetate. Pigments were analyzed by reversed phase HPLC after Wright et al. (1991). The samples were injected through a Waters 171 Plus autosampler into an Alltech column (Econosphere C18). The signal was detected at 436 and $658 \mathrm{~nm}$ with a Waters 440 absorbance detector. From the 0 to $1 \mathrm{~mm}$ layer 4 replicates per station were extracted in $95 \%$ methanol and buffered with ammonium acetate before injection. See Barranguet et al. (1997) for more information.

\section{RESULTS}

\section{Photic depth and 'fluorescence' depth}

Only 1 to $5 \%$ of the irradiance absorbed by a photosynthetic organism will be emitted as fluorescence. Therefore, in order to establish the 'measuring depth' of the PAM, we determined the irradiance attenuation in $1 \mathrm{~mm}$ sections of different cores using the MACAM spectroradiometer, assuming that irradiance decreased exponentially with depth (Eq. 4). As can be seen in Fig. 2, the attenuation of irradiance is very strong, but also rather variable among the different cores. The cores with a lower silt content (see Table 1) showed a lower irradiance attenuation. The increased absorption due to algae can be clearly seen as an absorption peak

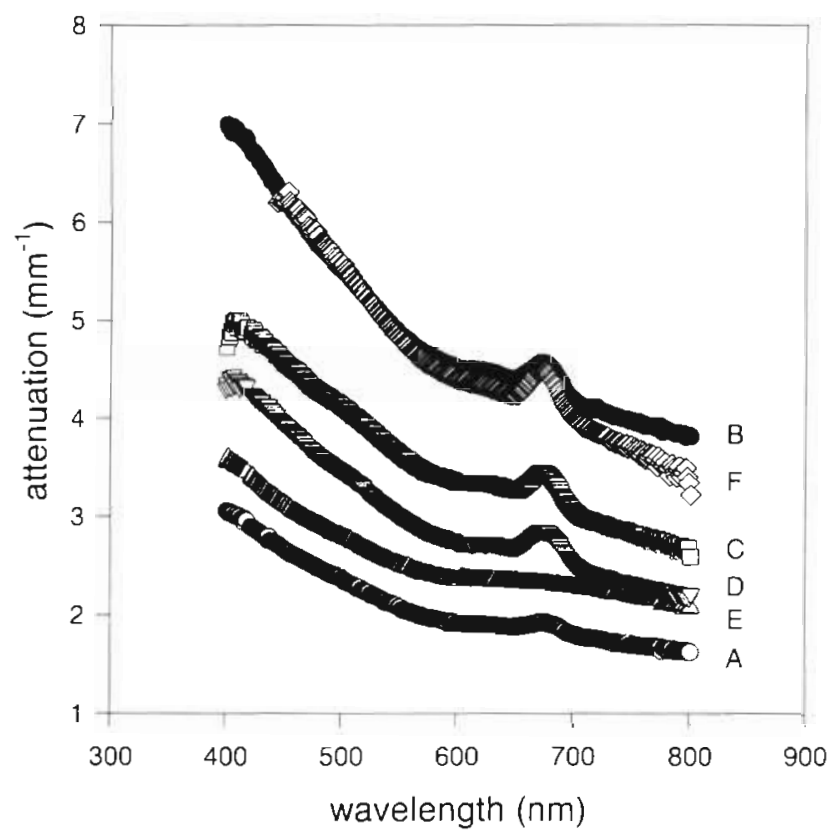

Fig. 2. Irradiance attenuation coefficients of sediments collected at Stns $A$ to $F$

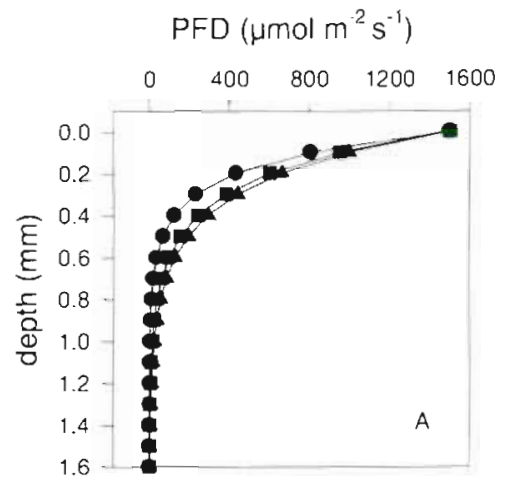

max. Fluorescence $\left(\mu \mathrm{mol} \mathrm{m} \mathrm{m}^{-2} \mathrm{~s}^{-1}\right)$

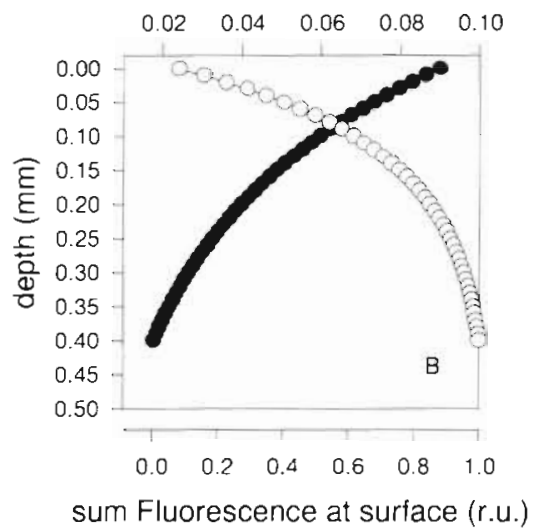

Fig. 3. Optical characteristics of the sediment. (A) Penetration of irradiance at 3 different wavelengths: $450(\mathbf{0}), 675(\mathbf{m})$ and 720 (4) nm. (B) Maximum fluorescence at depth (•), assuming that $5 \%$ of the light absorbed by chlorophyll is emitted as fluorescence. From this the total fluorescence at the surface was calculated $(0)$ using the attenuation coefficient of red light $\left(K_{\mathrm{d}, 720 \mathrm{~nm})}\right.$

near $675 \mathrm{~nm}$. The spectral attenuation coefficient at 3 different wavelengths was used to calculate the PFD at several depths at Stn B (Fig. 3A). It must be taken into account, however, that our estimates may be too low due to the intense scatter of light in sandy sediments (Kühl et al. 1994). In the range of the grain sizes of the Molenplaat, scattering can eventually double the total scalar irradiance just below the surface. As we did not possess fiber optic microprobes, we could not verify this. Like Kühl et al. (1994), we observed that nearinfrared light penetrates deeper into the sediments. As the light attenuation between 700 and $800 \mathrm{~nm}$ hardly varied, we chose to use the attenuation coefficient of light at $720 \mathrm{~nm}$ to calculate the amount of fluorescent light measured at the sediment surface. We assumed a diatom chlorophyll-specific absorption cross section of $0.008 \mathrm{~m}^{2}$ (mg chl) ${ }^{-1}$ (Kromkamp \& Limbeek 1993) and a

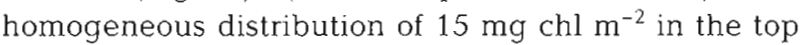
$1 \mathrm{~mm}$. From this we calculated the amount of PAR 
(400 to $700 \mathrm{~nm}$ ) absorbed at depth, assuming a surface photon irradiance of $1500 \mathrm{mmol} \mathrm{m}^{-2} \mathrm{~s}^{-1}$. At most, $5 \%$ of the irradiance absorbed is emitted as fluorescence. Using this percentage, we calculated the maximum fluorescence emission at depth, and from this, using Eq. (4) and $K_{\mathrm{d}, 720 \mathrm{~mm}}$, we calculated how much of the emitted fluorescence reached the sediment core surface (Fig. 3B). From this calculation, which gives only an indication of the depth detectable by the PAM, we conclude that most of the fluorescence $(75 \%)$ emanates from a depth less than $150 \mu \mathrm{m}$.

\section{Photosynthetic performance at different sites}

Fluorometric measurements were performed on all 6 stations in March, April and May only. Chlorophyll contents varied considerably, both over time and between stations, although the central stations, B and $F$, always contained the highest benthic algal biomass (Table 2). Despite the sharp differences in microphytobenthic biomass in March and May, the optimal quantum efficiency $F_{\mathrm{v}} / F_{\mathrm{m}}$ of dark adapted samples was quite similar, and varied between 0.53 and 0.66 , with the exception of Stn D (Table 2). This indicates that the physiological state of the benthic algae was similar, despite the differences in biomass. In April the maximum quantum efficiency was below 0.3, with the exception of Stn F. As fluorescence signals were low in April (and for Stn D in March), we had to use a high setting for measuring light and gain, and the data were very noisy and probably not reliable.

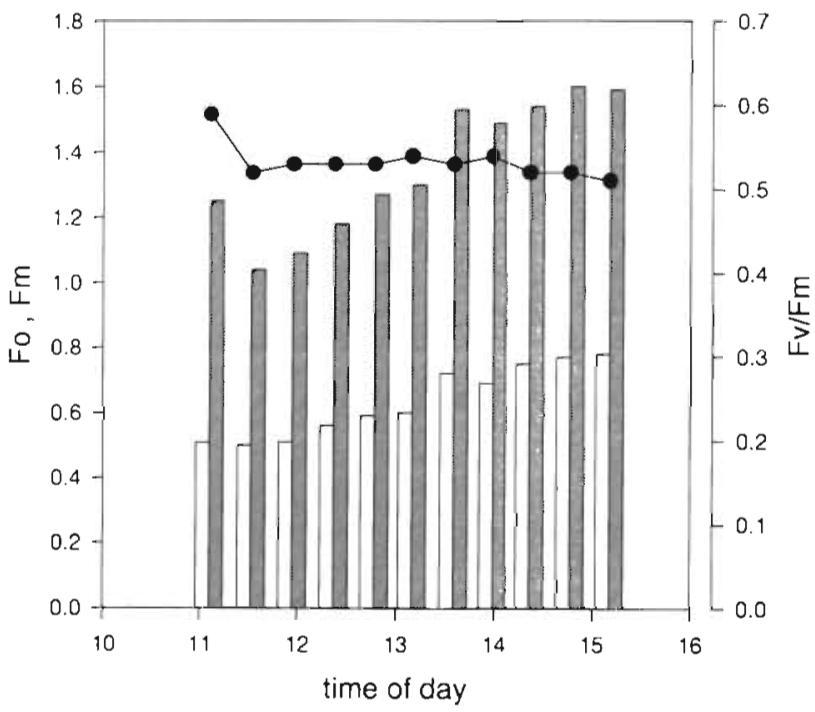

Fig. 4. Change in minimum ( $F_{0}$, open bars) and maximum $\left(F_{\mathrm{m}}\right.$ hatched bars) fluorescence yield and optimal quantum efficiency $\left(F_{\mathrm{v}} / F_{\mathrm{m}}, \bullet\right)$ with time (h) measured on June 2, 1995
Table 2. Chl a contents ( $\mathrm{mg} \mathrm{m}^{-2}$ ) and maximum quantum efficiency $\left(F_{\mathrm{v}} / F_{\mathrm{m}}\right)$ of benthic algae at the 6 different sampling stations. nd: not determined

\begin{tabular}{|c|c|c|c|c|c|c|}
\hline \multirow[t]{2}{*}{ Stn } & \multicolumn{2}{|c|}{ March } & \multicolumn{2}{|c|}{ April } & \multicolumn{2}{|c|}{ May } \\
\hline & $\mathrm{Chla}$ & $F_{\mathrm{v}} / F_{\mathrm{m}}$ & Chl a & $F_{\mathrm{v}} / F_{\mathrm{m}}$ & Chl a & $F_{\mathrm{v}} / F_{\mathrm{m}}$ \\
\hline A & 2.6 & 0.58 & 1.3 & 0.23 & 2.7 & 0.54 \\
\hline B & 23.0 & 0.63 & 14.1 & 0.22 & 13.3 & 0.53 \\
\hline C & 20.0 & 0.66 & 2.8 & 0.21 & 12.0 & 0.54 \\
\hline$D$ & 0.5 & 0.31 & 1.6 & 0.13 & 2.5 & 0.60 \\
\hline$E$ & 4.3 & nd & 4.4 & 0.26 & 9.7 & 0.61 \\
\hline$F$ & 25.6 & 0.54 & 15.9 & 0.53 & 8.0 & 0.56 \\
\hline
\end{tabular}

From June onwards only Stns B and A were visited. $F_{\mathrm{v}} / F_{\mathrm{m}}$ values were in general comparable between both stations, so we conclude that, despite the patchiness in biomass, the (photosynthetic) physiological state was not different.

\section{Temporal changes in photosynthetic performance}

Fig. 4 shows an example of changes in minimum and maximum fluorescence yields $\left(F_{\mathrm{o}}\right.$ and $\left.F_{\mathrm{m}}\right)$ and optimal quantum efficiency $\left(F_{\mathrm{v}} / F_{\mathrm{m}}\right)$ during the day of a core taken at Stn B on June 2, 1995. As can be seen, there was a gradual increase in both the minimum and maximum fluorescence yield, whereas $F_{\mathrm{v}} / F_{\mathrm{m}}$ remained constant. The proportional increase in both $F_{\mathrm{o}}$ and $F_{\mathrm{m}}$ indicates an increase in biomass near the surface,

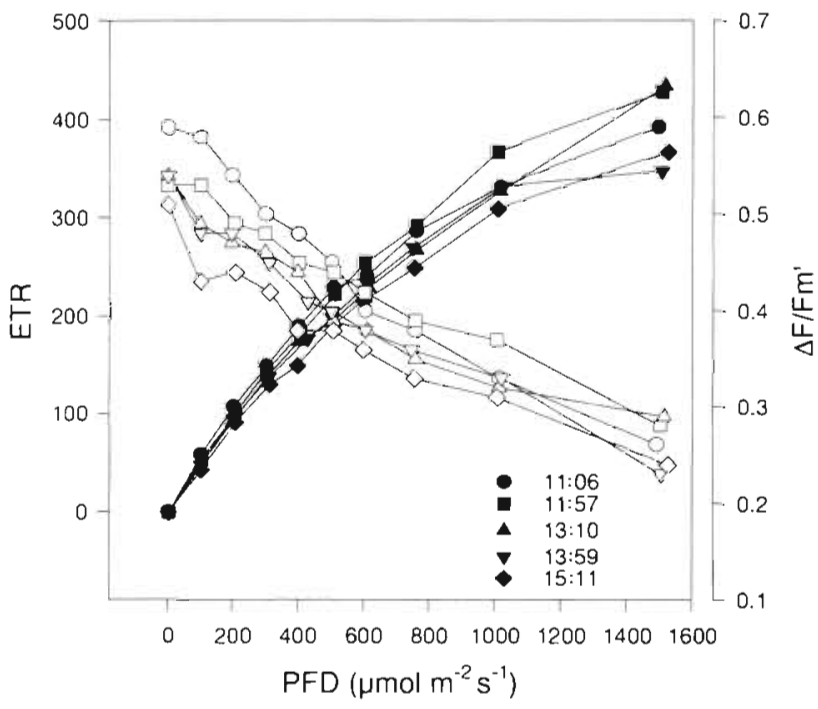

Fig. 5. Change in effective quantum efficiency $\left(\triangle F / F_{m}\right.$ ', open symbols) and relative photosynthetic electron transport ( $E T R$, closed symbols, relative units) with photon flux density (PFD) at different times during low tide. Core taken on June 2, 1995. Key shows time of day measurements were taken 


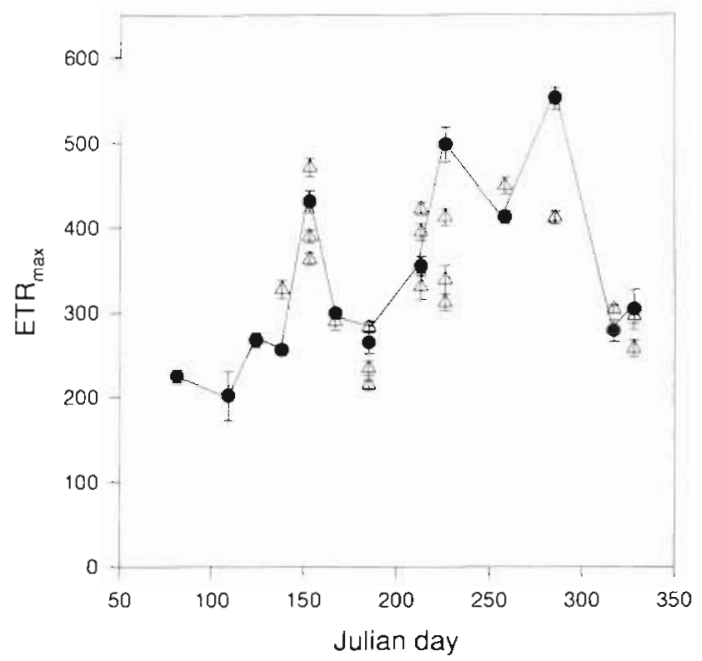

Fig. 6. Seasonal change in maximum rate of ETR at Str B. Error bars give the $95 \%$ confidence interval calculated from the Platt \& Jassby (1976) fit. The line connects the first measurements taken each day ( $)$, normally $1 \mathrm{~h}$ before low tide. As can be seen, on a number of days ETR $R_{\text {max }}$ changed during low tide $(\Delta)$. No consistent pattern could be observed in these daily changes

probably due to upward vertical migration. This will be discussed below.

Fig. 5 shows a typical example of the change in effective quantum efficiency $\left(\Delta F / F_{\mathrm{m}}{ }^{\prime}\right)$ when exposed to increasing PFDs at different times of the day of a core taken on June 2 at Stn B. The quantum efficiency of charge separation decreased from 0.6 to 0.25 , as more and more PSII traps closed with increasing PFD. The changes in $\Delta F / F_{\mathrm{m}}{ }^{\prime}$ in time were small. From the change in $\triangle F / F_{\mathrm{m}}{ }^{\prime}$ the relative $E T R$ was calculated as a measure of photosynthetic activity (Fig. 5). Because, in this example, the pattern in $\Delta F / F_{\mathrm{m}}{ }^{\prime}$ with PFD hardly varied at different times of the day, daily changes in ETR were very small. The pattern illustrated in Fig. 5, i.e. a rather constant photosynthetic activity throughout low tide, was observed on a number of days, whereas on other days, changes in $\Delta F / F_{\mathrm{m}}{ }^{\prime}$ with increasing PFD were larger, causing a decrease in photosynthetic activity during the day. The relative electron transport rates at different PFDs were fitted according to Platt \& Jassby (1976), and the maximum ETR, the 'photosynthetic affinity' $\alpha$ (i.e. the initial slope of an ETR vs PFD-plot) and the saturating PFDs $\left(I_{\mathrm{k}}=E T R_{\max } / \alpha\right)$ were calculated. The change in maximum $E T R$, a parameter comparable to the photosynthetic capacity $P_{\max }^{\mathrm{B}}$ is plotted in Fig. 6. The line connects the first samples (closed symbols), which were taken approximately $1 \mathrm{~h}$ before low tide. The triangles show the other measurements made on that day. In winter, $E T R_{\max }$ was low, most probably due to low temperatures; it rose to higher values in summer. The change in $E T R_{\max }$ observed on sev-

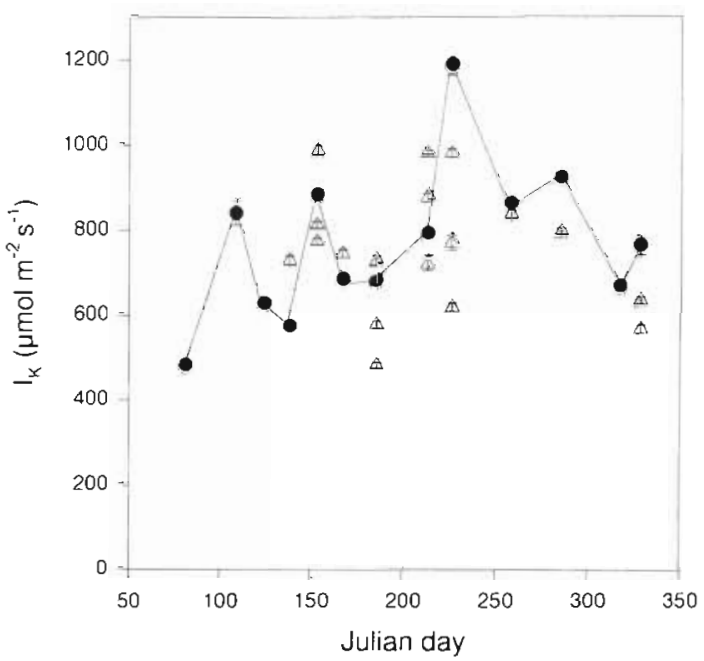

Fig. 7 . Seasonal change in the light saturation parameter $I_{k}$. It shows the same pattern as $E T R_{\max }$ (in Fig. 6). Symbols as in Fig. 6

eral days during low tide is not due to measuring errors, as the noise level is quite low, as indicated by the error bars (see also Fig. 9), but is caused by a change in photosynthetic activity during low tide. Note that on some days there was no significant change (Day 167) or a small change in maximum ETR (Days 317 and 328), whereas on most days there was a considerable change in $E T R_{\max }$ during low tide $(\mathrm{p}<$ 0.05 ). We could not find any consistent pattern in the changing activity, indicating the absence of nutrient limitation.

Between Days 160 and 210 there was a sudden dip in the maximum $E T R_{i}$ the possible reason for this will be discussed later. The photosynthetic affinity, $\alpha$, remained more or less constant during the year. During the day (or tidal exposure), $\alpha$ decreased, but the changes were not always significant. Because of this, $I_{\mathrm{k}}$, the saturating irradiance for ETR, showed more or less the same pattern as $E T R_{\max }$ : relatively low values in winter, higher values in spring and summer, and a strong decrease in values between Days 150 and 220 (Fig. 7), although the pattern was less clear than for $E T R_{\text {max }}$. In general the values were rather high as compared to $I_{\mathrm{k}}$ values previously measured for phytoplankton (determined from ${ }^{14} \mathrm{C}$-uptake rates), which varied between 250 and $300 \mu \mathrm{mol} \mathrm{m}{ }^{-2} \mathrm{~s}^{-1}$ (Kromkamp \& Peene 1995), indicating that the microphytobenthos community of the upper surface layer seems adapted to high light conditions.

The maximum quantum efficiency did not show a pattern similar to $E T R_{\max }$ or $I_{\mathrm{k}}$ (Fig. 8): values in winter and spring were similar and varied between 0.6 and 0.65. Daily or tidal patterns were less pronounced. Notice the decrease in $F_{\mathrm{v}} / F_{\mathrm{m}}$ between Days 200 and 


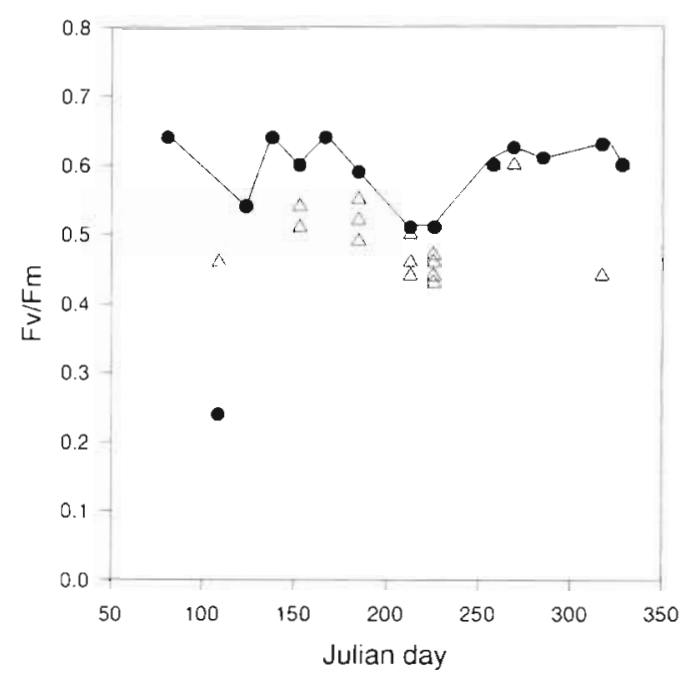

Fig. 8. Seasonal change in maximal PSII quantum efficiency. The line connects the first measurements of the day, usually taken $1 \mathrm{~h}$ before low tide. Notice that the decrease between Days 200 and 250 was observed later than the decrease in $E T R_{\max }$ or $I_{\mathrm{k}}$. Symbols as in Fig. 6. The low $F_{\mathrm{v}} / F_{\mathrm{m}}$ at around Day 105 was most likely due to a noisy signal

250: it did not correspond to the temporary decrease in $E T R_{\max }$ or $I_{\mathrm{k}}$, which was observed earlier that year.

\section{Vertical migration and absence of photoinhibition}

On June 29, a core, taken at Strn B, was exposed for $4 \mathrm{~h}$ to a PFD of $800 \mu \mathrm{mol} \mathrm{m} \mathrm{m}^{-2} \mathrm{~s}^{-1}$, during which the change in fluorescence was followed. As can be seen in Fig. 9, both $F_{\mathrm{s}}$ and $F_{\mathrm{m}}$ ' increased with time. From this it could be calculated that the effective quantum efficiency of PSII $\left(\Delta F / F_{\mathrm{m}}{ }^{\prime}\right)$ did not decrease, as might be expected after a prolonged exposure to the high PFD. On the contrary, $\triangle F / F_{\mathrm{m}}{ }^{\prime}$ increased slightly from 0.35 to 0.4 during the first $90 \mathrm{~min}$ of the incubation. This makes is likely that photoinhibition did not occur.

To see whether the increase in $F_{\mathrm{s}}$ and $F_{\mathrm{m}}$ ' was due to vertical migration, the reflected light was measured by a spectroradiometer. The reflectance $(R)$ spectra showed a decrease in reflection, especially in the blue and around $675 \mathrm{~nm}$, due to an increased absorption by chlorophyll (not shown). To make this more clear, we divided the measured reflectance spectrum at time zero by that at time $t$ in order to obtain a measure of the absorption spectrum. The first $R$ spectrum was taken as a reference value. Because the amount of microphytobenthos already present, as well as the sediment composition, may vary between days, it is not possible from these measurements to quantitatively estimate the chlorophyll content present. Nevertheless, the spectra are very well suited to demonstrate changes in

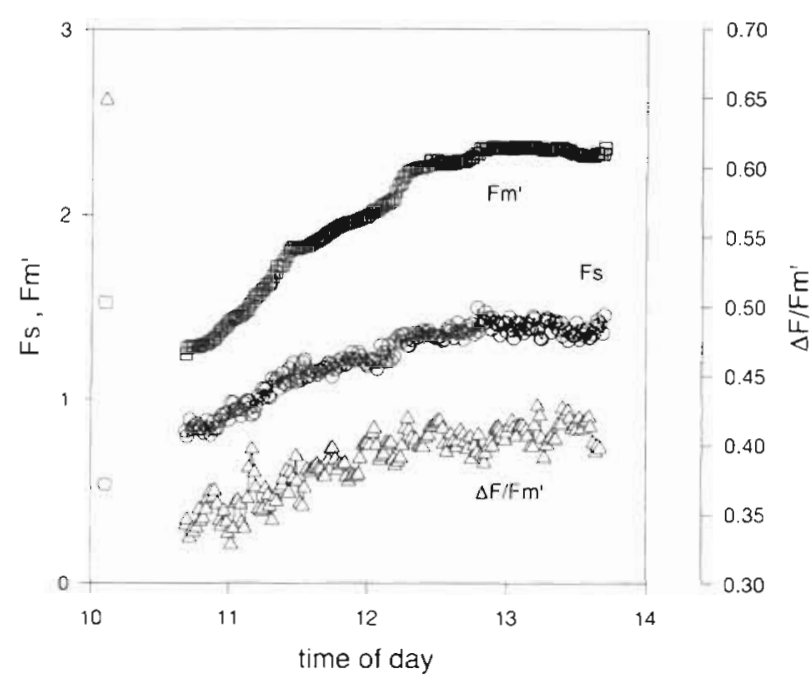

Fig. 9. Change in $F_{\mathrm{m}}{ }^{\prime}, F_{\mathrm{s}}$ and $\Delta F_{\mathrm{v}} / F_{\mathrm{m}}{ }^{\prime}$ with time when a core taken on June 29, 1995, was exposed to a PFD of $800 \mu \mathrm{mol} \mathrm{m}^{-2}$ $\mathrm{s}^{-1}$ Note that the noise is low, indicating that the change in $E T R_{\max }$ during the day (see Fig. 6 ) is not due to noise, but due to a change in activity

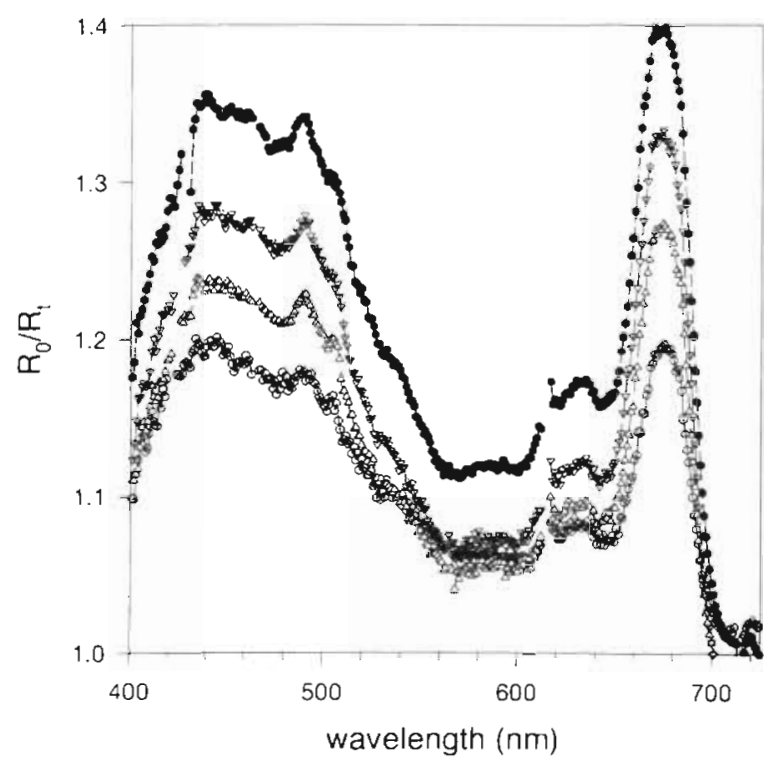

Fig. 10. Change in the reflection spectrum with time of a core taken on June 29, 1995. The R-spectrum, which resembles an algal absorption spectrum, was calculated by dividing the intitial spectral scan $\left(R_{0}\right)$ by a scan at time $t\left(R_{t}\right) .(0) 10: 13 \mathrm{~h}$; (ه) $11: 13 \mathrm{~h} ;(\nabla), 12: 13 \mathrm{~h} ;(\bullet) 14: 13 \mathrm{~h}$

the amount of algae at the sediment surface. As can be seen in Fig. 10, the spectrum very much resembled an algal absorption spectrum. There was no clear absorption due to phycoerythrin $(562 \mathrm{~nm})$ or phycocyanin $(620 \mathrm{~nm})$, indicating that cyanobacteria, if present in the microphytobenthos community at this station, 


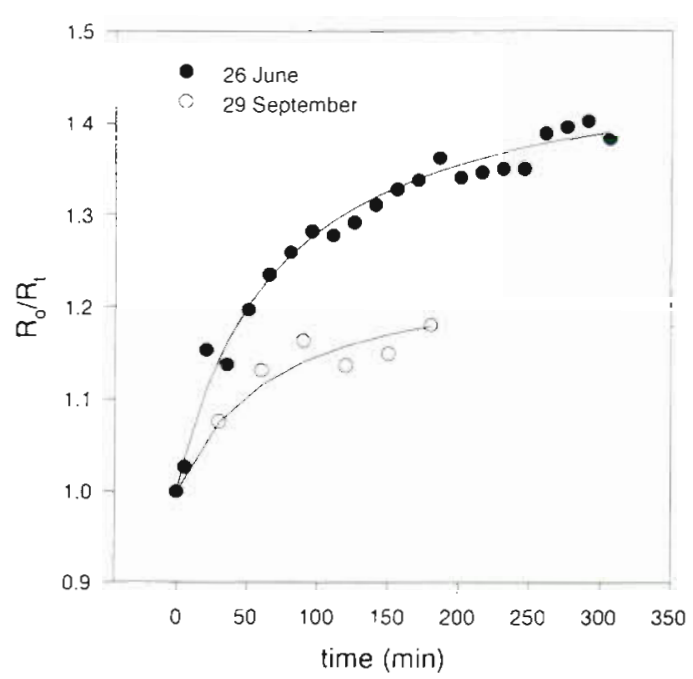

Fig. 11. Change in reflection at $\lambda=675 \mathrm{~nm}$ with time on 2 different days. Notice that $50 \%$ of the increase in reflection occurs within the first hour

played only a minor role at this time. It is also clear that the absorption at the sediment surface increased considerably, demonstrating a vertical migration of microphytobenthos to the sediment surface. A similar result was found when the experiment was repeated on September 29. When the change at $675 \mathrm{~nm}$ is plotted against time, it is clear that the initial migration activity is highest: $50 \%$ of the change in reflectance was observed in the first hour of the measurement (Fig. 11). This rapid migration will complicate areal primary production estimates, because the time scale of migration is within the time scale of the photosynthetic measurements normally employed.

\section{DISCUSSION}

The aim of this paper was to investigate whether active fluorescence, measured using a PAM fluorometer, can be used to follow changes in photosynthetic activity of microphytobenthos. It is clear from the results that the measured fluorescence only monitors the upper part of the microphytobenthic community, hence the technique as we employed it cannot be used directly to estimate areal primary productivity.

One has to be aware though that the PAM measures PSII quantum efficiency and that photosynthetic electron transport is calculated from this. Because the electrons are split from water, one might expect a close coupling between ETR and oxygen evolution (see also Kolber \& Falkowski 1993). However, due to the presence of electron sinks which can consume oxygen, like the Mehler reaction, and photorespiration, the rela- tionship between oxygen production and ETR is not necessarily linear, and especially at higher irradiance the relationship becomes non-linear (Geel et al. 1997, Flameling \& Kromkamp 1998). A change in the functional cross section of PSII might also influence the absolute rate of ETR (Kolber \& Falkowski 1993). Nevertheless, some interesting features were observed: the PAM could be used to construct ETR-PFD curves, analogous to the well known photosynthesis irradiance (P-I) curves. Because this was done in situ, the possible influence of microgradients in the upper surface layer were not disrupted, as is the case when P-I curves are made using slurries with the ${ }^{14} \mathrm{C}$-technique to measure $\mathrm{C}$-fixation. Hence, the change in photosynthetic parameters can be more easily linked to changes in the environment than when using $\mathrm{C}$-fixation methods.

When this was done, it was noticed that during low tide, a change in photosynthetic activity sometimes occurred, as has been observed before using ${ }^{14} \mathrm{C}$ (Blanchard \& Cariou-Le Gall 1994) or oxygen methods (e.g. Pinckney \& Zingmark 1993, Kromkamp et al. 1995a). Whether this change in activity was due to a true rhythmic activity, as suggested by Pinckney \& Zingmark (1993), or was due to some other factors, e.g. photoinhibition, $\mathrm{CO}_{2}$-limitation or backpressure, is not clear at present (but see below).

Seasonal changes in $E T R_{\max }$ and $I_{\mathrm{k}}$ were not related to changes in nutrient concentrations: in the overlying water, nitrate concentrations were above $100 \mu \mathrm{M}$ all the time. Ammonia concentrations during Days 160 to 180 changed from 12 to $7 \mu \mathrm{M}$. Silicate $(>20 \mu \mathrm{M})$ and phosphate $(>3 \mu \mathrm{M})$ also did not reach limiting concentrations. Pore water concentrations in the upper $\mathrm{cm}$ were even higher (ammonia up to $600 \mu \mathrm{M}$, silicate up to $400 \mu \mathrm{M}$ and phosphate up to $175 \mu \mathrm{M}$; K. Perry pers. comm.). Nevertheless, in a dense mat local depletion cannot be ruled out completely, but we do not think this is likely. Between Days 160 and 210, lower values for $E T R_{\max }$ and $I_{\mathrm{k}}$ were found. In the period from Day 160 to 180 , the average daily light dose was approximately $25 \mathrm{~mol}$ photons $\mathrm{m}^{-2}$, whereas in the preceding and following fortnight the light dose was nearly twice as high (not shown). This indicates that the observed pattern in $E T R_{\max }$ and $I_{\mathrm{k}}$ might reflect photoacclimation.

According to Falkowski et al. (1992), nutrient limitation will decrease the optimal quantum efficiency. This has been demonstrated for nitrogen limitation (Kolber et al. 1988), iron limitation (Geider et al. 1993) and for phosphorus limitation (Geider et al. 1993, Flameling \& Kromkamp unpubl.). As noted above, the change in optimal quantum efficiency of PSII (see Fig. 8) is unlikely to be due to a limitation in the macronutrients $\mathrm{N}, \mathrm{P}$ or Si. The fact that no consistent pattern in the change in $F_{\mathrm{v}} / F_{\mathrm{m}}$ during low tide could be observed also 
corroborates the hypothesis that nutrient limitation did not occur. As the $\mathrm{CO}_{2}$ concentrations in the water are high, we find it unlikely $\mathrm{CO}_{2}$ will be limiting at the start of the low tide. Additional experiments in which $\mathrm{CO}_{2}$ or bicarbonate were added confirmed this. The same was observed after enrichment of a core with ammonia (not shown). On the other hand, we cannot rule out that, as the time progresses during the day at low tide, a $\mathrm{CO}_{2}$ limitation develops. On the contrary, this is very likely and has been argued before (de Jong et al. 1990 , Glud et al. 1992).

The $F_{v} / F_{\mathrm{m}}$ values are below 0.8 , the value typically found in higher plants. However, algae, especially chl $C$ containing microalgae, show a lower optimal $F_{\mathrm{v}} / F_{\mathrm{m}}$ (Ting \& Owens 1992, Ibelings et al. 1994, Flameling \& Kromkamp 1995, Kromkamp et al. 1995b; see Büchel \& Wilhelm 1993 for a review on algal fluorescence). We therefore conclude from the $F_{\mathrm{v}} / F_{\mathrm{m}}$ ratio that the PSII reaction centres were fully functional and that nutrient limitation by $N, P$ or Si did not occur. This argument leaves unexplained the decrease in $F_{\mathrm{v}} / F_{\mathrm{m}}$ between Days 200 and 250. For this we have no explanation, only that it seems to coincide with a change in species composition: normally the microphytobenthos community at Stn B is composed of benthic diatoms, but for the period that coincided with the lower $F_{\mathrm{v}} / F_{\mathrm{m}}$ values, the intertidal flat was coloured green instead of brown, and the dominant benthic alga in this period was a Euglena species.

When a sediment core was exposed to a high PFD for several hours, upward vertical migration could be clearly demonstrated (see Figs. $10 \& 11$ ). The observed pattern in apparent quantum efficiency $\Delta F / F_{\mathrm{m}}$ ' showed a small increase, and not, as expected by us, a decrease. Exposure for a prolonged period to a high photon irradiance will most likely initiate energy quenching, i.e. energy dissipation as heat. This (dynamic) down-regulation of photosynthesis is viewed as a protective mechanism against chronic photoinhibition (Horton \& Ruban 1994, Osborne 1994). Down-regulation (i.e. energy quenching) as a result of sunlight has been observed in leaves (e.g. Bilger et al. 1995), macroalgae (Osmond et al. 1993, Hanelt et al. 1994) and unicellular algae (Kroon et al. 1994, Flameling \& Kromkamp 1995, Ibelings et al. 1995, Kromkamp et al. $1995 \mathrm{~b}$ ) and is a process which can be induced (and relax) very rapidly. On intertidal flats, high PFDs will lead to high rates of photosynthesis. This will cause a pH-rise and probably a lack of $\mathrm{CO}_{2} \cdot \mathrm{CO}_{2}$ limitation has been inferred before (Rasmussen et al. 1983, de Jong et al. 1988, 1990, Glud et al. 1992). If Rubisco is limited by substrate, this will induce backpressure effects at PSII and cause accumulation of reduced $Q_{A}$; this will decrease the efficiency of charge separation, and thus lower $\Delta F / F_{m}{ }^{\prime}$. A decrease in $\Delta F / F_{\mathrm{m}}{ }^{\prime}$ was, however, not observed during the experiments in high irradiance, indicating no shortage of $\mathrm{CO}_{2}$ to the upper part of the benthic population. It is, however, unlikely that high rates of photosynthesis can be sustained by $\mathrm{CO}_{2}$ and that down-regulation of photosynthetic activity will not occur. We therefore think it is more likely that during the overall vertical migration to the upper layer, there is a vertical 'micro'-migration within the first mm of the sediment where algae at the surface migrate to deeper layers in order to prevent photoinhibition and $\mathrm{CO}_{2} \mathrm{lim}$ itation, and are replaced by others.

These results also show that it is impossible to estimate the areal primary productivity of microphytobenthos accurately using current techniques. When the light-dark oxygen micro-electrode technique is used (Revsbech \& Jørgensen 1993), construction of gross photosynthesis-irradiance curves takes too much time: within the time scale of the measurement, vertical migration will have occurred. On the other hand, when the ${ }^{14} \mathrm{C}$-technique is used and the benthic algae are resuspended in filtered seawater (e.g. Blanchard \& Cariou-Le Gall 1994), the vertical distribution of the algae will be disrupted, as will all the chemical gradients, or in the case of chamber techniques, the specific activity of the ${ }^{14} \mathrm{C}$ in the sediment is not known. Maybe the most realistic method therefore is to measure the oxygen profile using micro-electrodes, and from sediment and diffusion characteristics, calculate the net primary production with the aid of a 1-dimensional diffusion-reaction model (Wiltshire 1992, Epping \& Jørgensen 1996).

Acknowledgements. We thank Jan Sinke for the HPLC-pigment analyses, Adri Merckx for the nutrient analysis, and the crew from RV 'Luctor' for their assistance in the field. This is communication 2364 from the NIOO-CEMO.

\section{LITERATURE CITED}

Barranguet C, Herman PMJ, Sinke JJ (1997) Microphytobenthos biomass and community composition studied by pigment biomarkers. Importance and fate in the carbon cycle of a tidal flat. J Sea Res 38:59-70

Bilger W, Schreiber U, Bock M (1995) Determination of the quantum efficiency of photosystem II and of non-photochemical quenching of chlorophyll fluorescence in the field. Oecologia 102:425-432

Blanchard GB, Cariou-Le Gall V (1994) Photosynthetic characteristics of microphytobenthos in Marennes-Oléron Bay, France: preliminary results. J Exp Mar Biol Ecol 182:1-14

Büchel C, Wilhelm C (1993) In vivo analysis of slow chlorophyll fluorescence induction kinetics in algae: progress, problems and perspectives. Photochem Photobiol 58: $137-148$

Colijn F (1983) Primary production in the Ems-Dollard estuary. PhD thesis, University of Groningen

Dau H (1994) Short-term adaptation of plants to changing light intensities and its relation to Photosystem II photo- 
chemistry and fluorescence. J Photochem Photobiol B: Biol $26: 3-27$

de Jong DJ, de Jonge VN (1995) Dynamics of microphytobenthos chlorophyll-a in the Scheldt estuary (S.W. Netherlands). Hydrobiologia 311:21-30

de Jong SA, Hofman PAG, Sandee AJJ (1988) Construction and calibration of a rapicly responding $\mathrm{pH}$ mini-electrode: application to intertidal sediments. Mar Ecol Prog Ser 45: $187-192$

de Jong SA, Hofman PAG, Sandee AJJ, Jansen HAPM (1990) Impact of different inorganic carbon sources on benthic microalgal photosynthesis in the Oosterschelde estuary. The Netherlands. In: de Jong SA, Hofman PAG, Wagenvoort EJ (eds) Primary production of benthic microalgae in the Oosterschelde estuary (S.W. Netherlands). Balans Report 43 Delta Institute for Hydrological Research, Yerseke, p 38-85

Epping EH, Jørgensen BB (1996) Light-enhanced oxygen respiration in benthic phototrophic communities. Mar Ecol Prog Ser 139:193-203

Falkowski PG, Greene RM, Geider RJ (1992) Physiological limitations on phytoplankton productivity in the ocean. Oceanography 5:84-91

Flameling IA, Kromkamp J (1995) Regulation of photosynthesis of Phaeocystis globosa in fluctuating light. In: Mathis P (ed) Photosynthesis: from light to biosphere, Vol V. Kluwer Academic Publishers, Dordrecht, p 797-800

Flameling IA, Kromkamp J (1998) Light-dependence of quantum yields for PSII charge separation and oxygen evolution in eucaryotic algae. Limnol Oceanogr (in press)

Geel C, Versluis W, Snel JFH (1997) Estimation of oxygen evolution by marine phytoplankton from measurement of the efficiency of photosystem II electron flow. Photosynth Res 51:61-70

Geider RJ, LaRoche J, Greene RM, Olaizola M (1993) Response of the photosynthetic apparatus of Phaeodactylum tricornutum (Bacillariophyceae) to nitrate, phosphate, or iron starvation. J Phycol 29:755-766

Genty B, Briantais JM, Baker NR (1989) The relationship between quantum yield of photosynthetic electron transport and quenching of chlorophyll fluorescence. Biochim. Biophys Acta 990:87-92

Glud RN, Ramsing NB, Revsbech NP (1992) Photosynthesis and photosynthesis-coupled respiration in natural biofilms quantified with oxygen microsensors. J Phycol 28:51-60

Hanelt D, Li J, Nultsch W (1994) Tidal dependence of photoinhibition of photosynthesis in marine macrophytes of the south China Sea. Bot Acta 107:66-72

Heip CHR, Goosen NK, Herman PMJ, Kromkamp J, Middelburg JJ, Soetaert K (1995) Production and consumption of biological particles in temperate tidal estuaries. Oceanogr Mar Biol Annu Rev 33:1-149

Hofstraat JW, Peeters JCH, Snel JFH, Geel C (1994) Simple determination of photosynthetic efficiency and photoinhibition of Dunaliella tertiolecta by saturating pulse fluorescence measurements. Mar Ecol Prog Ser 103:187-196

Holland A, Zingmark R, Dean J (1974) Quantitative evidence concerning the stabilization of sediments by marine benthic diatoms. Mar Biol 27:191-196

Horton P, Ruban A (1994) The role of light-harvesting complex II in energy quenching. In: Baker NR, Bowyer JR (eds) Photoinhibition of photosynthesis: from molecular mechanisms to the field. BIOS Scientific Publishers, Oxford, p 111-128

Ibelings BW, Kroon BNA, Mur LR (1994) Acclimation of photosystem II in a cyanobacterium and a eukaryotic green alga to high and fluctuating photosynthetic photon flux densities, simulating light regimes induced by mixing in lakes. New Phytol 128:407-424

Kolber Z, Falkowski PG (1993) Use of active fluorescence to estimate phytoplankton photosynthesis in situ. Limnol Oceanogr 38:1646-1665

Kolber Z, Zehr J, Falkowski PG (1988) Effects of growth irradiance and nitrogen limitation on photosynthetic energy conversion in photosystem II. Plant Physiol 88:923-929

Krause GH, Weis E (1991) Chlorophyll fluorescence and photosynthesis: the basics. Annu Rev Plant Physiol Plant Mol Biol 42:313-349

Kromkamp J, Limbeek M (1993) Effect of short-term variation in irradiance on light harvesting and photosynthesis of the marine diatom Skeletonema costatum: a laboratory study simulating vertical mixing. J Gen Microbiol 139: $2277-2284$

Kromkamp J, Peene J (1995) Possibility of net phytoplankton primary roduction in the turbid Schelde estuary (SW Netherlands). Mar Ecol Prog Ser 121:249-259

Kromkamp J, Peene J, Flameling IA (1995b) Photosynthetic performance of Emiliania huxleyi in a fluctuating light climate simulating vertical mixing. In: Mathis P (ed) Photosynthesis: from light to biosphere, Vol V. Kluwer Academic Publishers, Dordrecht, p 793-796

Kromkamp J, Peene J, van Rijswijk P, Sandee A, Goosen N (1995a) Light, nutrients and primary production by phytoplankton and microphytobenthos in the eutrophic, turbid Westerschelde Estuary (The Netherlands). Hydrobiologia 311:9-19

Kroon BMA (1994) Variability of photosystem II quantum yield and related processes in Chlorella pyrenoidosa (Chlorophyta) acclimated to an oscillating light regime simulating a mixed photic zone. J Phycol 30:841-852

Kühl M, Lassen C, Jørgensen BB (1994) Light penetration and light intensity in sandy marine sediments measured with irradiance and scalar irradiance fiber-optic microprobes. Mar Ecol Prog Ser 105:139-148

MacIntyre HL, Cullen JJ (1995) Fine-scale vertical resolution of chlorophyll and photosynthetic parameters in shallowwater benthos. Mar Ecol Progr Ser 122:227-237

Ohad I, Keren N, Zer H, Gong $H$, Mor TS, Gal A, Tal S, Domovich Y (1994) Light-induced degradation of the photosystem Il reaction centre D1 protein in vivo: an integrative approach. In: Baker NR, Bowyer JR (eds) Photoinhibition of photosynthesis: from molecular mechanisms to the field. BIOS Scientifc Publishers, Oxford, p 161-178

Osborne BA (1994) Photon requirement for $\mathrm{O}_{2}$-evolution in red $(\lambda=680 \mathrm{~nm})$ light for some $\mathrm{C}_{3}$ and $\mathrm{C}_{4}$ plants and a $\mathrm{C}_{3} \cdot \mathrm{C}_{4}$ intermediate species. Plant Cell Environ 17:143-152

Osmond CB (1994) What is photoinhibition? Some insights from comparison of shade and sun plants. In: Baker NR, Bowyer JR (eds) Photoinhibition of photosynthesis: from molecular mechansims to the field. BIOS Scientifc Publishers, Oxford, p $1-24$

Osmond CB, Ramus J, Levavasseur G, Franklin LA, Henley WJ (1993) Fluorescence quenching during photosynthesis and photoinhibition of Ulva rotundata Blid. Planta 190: $97-106$

Paterson DM (1989) Short-term changes in the erodibility of intertidal cohesive sediments related to the migratory behaviour of epipelic diatoms. Limnol Oceanogr 34: $223-234$

Pinckney J, Zingmark RG (1991) Effects of tidal stage and sun angles on intertidal benthic microalgal productivity. Mar Ecol Prog Ser 76:81-89

Pinckney J, Zingmark RG (1993) Biomass and production of benthic microalgal communities in estuarine habitats. Estuaries 16:887-897 
Platt T, Jassby AD (1976) The relationship between photosynthesis and light for natural assemblages of coastal marine phytoplankton. J Phycol 12:421-430

Rasmussen MB, Henriksen K, Jensen A (1983) Possible causes of temporal fluctuation in primary production of the microphytobenthos in the Danish Wadden Sea. Mar Biol 73: 109-114

Revsbech NP, Jørgensen BB (1983) Photosynthesis of benthic microflora measured with high spatial resolution by the oxygen microprofile method: capabilities and limitations of the method. Limnol Oceanogr 28:749-756

Sullivan M, Moncreiff C (1988) Primary production of edaphic algal communities in a Mississippi salt marsh. J Phycol 31: $49-58$

Sullivan M, Moncreiff C (1990) Edaphic algae are an important component of salt marsh food-webs: evidence from multiple stable isotope analysis. Mar Ecol Prog Ser 32: $149-159$

Ting CS, Owens TG (1992) Limitations of the pulse-modu-

Editorial responsibility: Otto Kinne (Editor)

Oldendorf/Luhe, Germany lated technique for measuring the fluorescence characteristics of algae. Plant Physiol 100:367-373

van Kooten O, Snel JFH (1990) The use of chlorophyll fluorescence nomenclature in plant stress physiology. Photosynth Res 25:147--150

Wiltshire KH (1992) Untersuchungen zum Einfluß des Mikrophytobenthos auf den Nährstoffaustausch zwischen Sediment und Wasser in der Tide-Elbe. PhD thesis, University of Hamburg, GKSS 92/E/47

Wright SW, Jeffrey SW, Mantoura RFC, Llewellyn CA, Bjornland T, Repeta D, Welschmeyer N (1991) Improved HPLC method for the analysis of chlorophylls and carotenoids from marine phytoplankton. Mar Ecol Prog Ser 77 : 183-196

Yallop ML, de Winder B, Paterson DM, Stal LJ (1994) Comparative structure, primary production and biogenic stabilisation of cohesive and non-cohesives marine sediments inhabited by microphytobenthos. Estuar Coast Shelf Sci 39:565-582

Submitted: December 18, 1996; Accepted: December 12, 1997 Proofs received from author(s): January 29, 1998 